\title{
A Review on Green Building Index: Management Criteria
}

\author{
Nasim Aghili ${ }^{a}$, Abdul Hakim Mohammed ${ }^{a *}$, Low Sheau-Ting ${ }^{b}$ \\ ${ }^{a}$ Department of Real Estate, Universiti Teknologi Malaysia, 81310 UTM Johor Bahru, Johor, Malaysia \\ ${ }^{b}$ Center for Real Estate Studies, Institute for Smart Infrastructure and Innovation Construction, Universiti Teknologi Malaysia, 81310 UTM Johor Bahru, \\ Johor, Malaysia \\ *Corresponding author: abdhakim@utm.my
}

\begin{abstract}
This paper reviews "management" criteria in green building standard worldwide. There are several issues related to the "management" criteria of green building that include the increase of property management and maintenance costs, the occurrence of incompatible maintenance programs, underutilization of property, end-user dissatisfaction, role of manager; lack of knowledge, skill and experience; and lack of proper financial planning. Twenty-seven green building indexes are reviewed. Summary of "management" criteria are presented from six green building standards. Current study has been proposed a set of "management criteria".
\end{abstract}

Keywords: Green building index; management criteria

(C) 2016 Penerbit UTM Press. All rights reserved

\subsection{INTRODUCTION}

In the current study, the researchers investigated about the management criteria in Malaysian Green Building Index. The management of Green Buildings (GB) considered as an important factor all over the world, since the growth and construction actions were recognized as one of the most important reasons of pollution in several countries. Results of the investigations of the management criteria regarding the green and conventional structures, shows that while green buildings are focused, all of the related directors know about its existence but they do not know how to manage it (Kamarudin, 2013). Due to that, building segment considered as the main basis of greenhouse gas emissions all over the world (Hong et al., 2007; Wu and Low, 2010a). Buildings conserve an important significant amount of energy that is around one-third of the entire main energy capitals all over the world (Aliagha et al., 2013; Shaikh et al., 2014). The building segment contributes about $30 \%$ of global greenhouse gas emissions yearly and uses up to $40 \%$ of the entire energy (Initiative, 2009). It should be noted that during the recent years, greenhouse gas emissions increased dramatically in Malaysia. Based on the United Nations Development Report, Malaysia with 27 million persons ranks as the 26th main greenhouse gas emitter all over the world. The building and construction is among the main contributors of CO2 emissions in Malaysia (Begum and Pereira, 2010).

GB considered as a building which is planned, created and worked to be resource-efficient (Mokhtar Azizi et al., 2012). In other words, GB considered as of the most important issues for improving and safeguarding the environment and developing the energy efficiency, reducing air pollution and water pollution, saving natural supply like gas, energy and water, mounting cost-efficiency, developing the lifestyle and finally optimizing the life-cycle charge (Bond, 2011; Geng et al., 2012; Richardson and Lynes, 2007; Zhang et al., 2011). GB usually emphases on developing the efficacy of supply usage such as energy, water, and resources while decreasing building influence on humanoid well-being and the environment throughout the construction's lifespan, over improved sitting, enterprise, building, action, upkeep, and removal. GB must be planned and worked for reducing the inclusive effect of the built environment on its surrounds (Halim, 2012). GB management could be explained as a win-win-win explanation regarding the building management, landlords, and occupants. Using green activities in the building management permits important cost savings for several years (Goodman, 2008).

The consciousness regarding the necessity of handling the building in an operative method is understood to be existing which expands in a positive way. There are several declarations that show that the nation has problems to manage its property resources. In fact, there is usually five main management issue in handling Malaysian government owned property assets. Those subjects are absence of appropriate property unit/department in a ministry, absence of skill, absence of appropriate plans, and absence of appropriate management process and absence of IT practice (Abdullah et al., 2011). Based on Tium (2006) the management scheme experienced in Malaysia likewise needs appropriate monetary planning. There is not any suitable preparation of the annual outflow and the inhabitants are neither informed nor have any say in the annual management budget. Consequently, performing the green property management is to mix all the green basics into the management process. Based on the property management criteria, the most important difficulty in property management refers to the goal achievements regarding the owner over a perfect enterprise of a management plan over a perfect maintenance, accounting, safety issues and managerial strategies (Kamarudin, 2013). The Malaysian property management industry today considered as more complicated and problematic (Tiun, 2006). The management scheme in Malaysia usually does not include a long term planning policy particularly regarding the upkeep of usual amenities (Tiun, 2006). The fact refers to the point that for managing the 
improvement of several kinds of possessions properties, Malaysia faced several challenges and drawbacks like the growth of property management as well as maintenance charges, the incidence of mismatched maintenance plans, underutilization of stuff, end-user displeasure and related items. Following this issue, the investigation was applied with the key purpose for identifying the management issues which are obstructing the performance of property management actions (Abdullah et al., 2011).

Definitely, at the same time in Malaysia, investigations about the property management are normally and moderately conducted during the recent years. Though to date, there was not exact investigation for identifying the matters, weaknesses or challenges associated to property management of the Malaysian context (as the investigation conducted by the AC in the United Kingdom) (Abdullah et al., 2011). Comparing with the building management system done in associated countries particularly in UK, Australia and Canada, the management of GB in Malaysia is still far behind those regions. According to World Green Building Council, the member countries are generally categorized into three groups: Established, Emerging, and Prospective based on the maturity and their development. An "Established" status GB council member is one that is fully operational displaying stability and national positioning. An "Emerging" status GB council member has developed its organization to a point where it is operational and beginning to roll out various programmers and initiatives. A "Prospective" status GB council member is one that has brought together a robust group of founding members, developed a strategic plan for how the GBC will be developed, and is registered as a legal entity. A review of the GB standards from all GB council members reveals that most of the countries in "Established" membership status has inclusion of "Management" as one of the criterion in their GB standard. Malaysia is among the few from the countries with "Established" status that do not has such criteria in the GB standard. The inclusion of the "Management" criteria in existing Malaysia Green Building Index is needed. A set of management practice considered as an important attribute for ensuring that the green building could be managed well. Regrettably, GBI in Malaysia does not include the criteria specially provide guide on management of the green building after the certification awarded. Therefore, this study aims to propose management criteria for Malaysian GBI which appropriate for management of the GB in Malaysia.

Table 1 Green building index vs. others

\begin{tabular}{|c|c|c|c|c|c|}
\hline GB Standard & $\begin{array}{c}\text { BREEAM } \\
\text { UK }\end{array}$ & $\begin{array}{c}\text { LEED } \\
\text { USA }\end{array}$ & $\begin{array}{c}\text { Green Star } \\
\text { Australia }\end{array}$ & $\begin{array}{c}\text { Green Globe } \\
\text { Canada }\end{array}$ & $\begin{array}{c}\text { GBI } \\
\text { Malaysia }\end{array}$ \\
\hline $\begin{array}{l}\text { Assessment } \\
\text { Criteria }\end{array}$ & $\begin{array}{l}\text { 1.Management } \\
\text { 2.Energy use } \\
\text { 3. Health and well } \\
\text { being } \\
\text { 4.Pollution } \\
\text { 5.Transport } \\
\text { 6.Land use and } \\
\text { ecology } \\
\text { 7.Materials } \\
\text { 8. Water } \\
\text { 9.Innovation }\end{array}$ & $\begin{array}{l}\text { 1.Sustainable sites } \\
\text { 2.Water efficiency } \\
\text { 3.Energy and Atmosphere } \\
\text { 4.Materials and Resources } \\
\text { 5.Indoor Environmental } \\
\text { Quality } \\
\text { 6.Innovation \& design } \\
\text { process }\end{array}$ & $\begin{array}{l}\text { 1.Management } \\
\text { 2.Indoor } \\
\text { Environmental } \\
\text { Quality } \\
\text { 3.Energy } \\
\text { 4.Transport } \\
\text { 5.Water } \\
\text { 6.Land use \& Ecology } \\
\text { 7.Emissions } \\
\text { 8.Material } \\
\text { 9.Innovation }\end{array}$ & $\begin{array}{l}\text { 1.Project Management } \\
\text { 2.Site Development } \\
\text { area } \\
\text { 3.Energy } \\
\text { 4. Water } \\
\text { 5.Resource } \\
\text { 6.Emissions, Effluents } \\
\text { \& Other Impacts } \\
\text { 7. Indoor Environment }\end{array}$ & $\begin{array}{l}\text { 1.Energy Efficacy } \\
\text { 2.Indoor Environmental } \\
\text { Quality } \\
\text { 3.Sustainable Site } \\
\text { Planning \& } \\
\text { Management } \\
\text { 4.Material \& Resources } \\
\text { 5.Water Efficiency } \\
\text { 6.Innovation }\end{array}$ \\
\hline
\end{tabular}

\subsection{WORLD GB STANDARD}

The World Green Building Council (World GBC) founded in November of 1999 in California, United States, which comprise eight countries such Australia, Canada, Japan, Spain, Russia, United Arab Emirates, United Kingdom and the United States. Formal combination of the World GBC tracked in 2002, its main role being for formalizing the international infrastructures. World GBC is the world's biggest association affecting the sustainable built environment with the corporation of around 100 countries all over the world (world Green Building Council, 2009).

Green rating equipment's for assessing and identifying the environmental activity of a building gained a global admiration. Thus, a plethora of green building standard with several rating standards were arisen like the UK Building Research Establishment's Environmental Assessment Method (BREEAM) in 1990, USA Leadership in Energy and Environmental Design (LEED) in 1998, Japan Comprehensive Assessment System for Building Environment Efficiency (CASBEEM) on June 2004, Norway Eco Profile on September 2010 (Geng et al., 2012). Likewise, Singapore Green Building Council (SGBC) started on 28 October 2009 (Hwang and Tan, 2012).

The GB assessment standards covers in this works contain BREEAM, LEED, Green Star, Green Globe and GBI. Table 1 summarizes the assessment criteria applied by each of these GB standards.

This section describes the overview of Green Building Standards in the world. The Building Research Establishment Environmental Assessment Method (BREEAM) in UK 1990 considered as the first inclusive building act assessment approach and it remains the most extensively applied (Crawley and Ilari, 1999; Thomas, 2008). BREEAM sets the criteria in the UK and several regions all over the world. BREEAM caused a significant effect on worldwide; Canada, Australia, Hong Kong and related regions that are using BREEAM methodology to improve their personal environmental construction assessment approaches (Ding, 2008). These are nine assessment standards in BREEAM like: management, energy consumption, well-being, pollution, transportation, land use and ecology, material, water as well as innovation (The World Green Building Council, 2009).

The Leadership in Energy and Environmental Design (LEED) was initially started in USA 1998 (Thomas saunders, 2008). In about ten years, the U.S. Green Building Council was developed as one of the significant effective instances of non-profit membership organization improvement during the recent years (Cassidy, 2003). LEED is flexible enough for applying all kind of commercial and residential buildings. Additionally, LEED authorization is obtainable for all kinds of buildings counting novel building and chief makeover, present structures, commercial centers, core and shell, schools and households, marketing and healthcare amenities (Seo, 2002; Thomas saunders, 2008). LEED assessed the performance of buildings based on several issues such as sustainable sites, water efficacy, energy and atmosphere, material and resource, indoor environmental quality and innovation and design process (Kasai and Jabbour, 2014). 
Green Star launched in Australia 2003 that was industrialized by the Green Building Council (Australia, 2009; Banani et al., 2011). BREEAM was applied as the foundation of the Green Star practice the two approaches are very comparable. Though, changes were applied to show several alterations amongst Australia and the UK, like the weather condition, local setting and the building industry typical rehearsal (Thomas saunders, 2008). Green Star assessed the green features of construction schemes based on nine categories, management, indoor environmental quality, energy, transportation, water, material, land use and ecology, emissions and innovation (The World Green Building Council, 2009).

The Green Globes in Canada is a radical construction environmental project and organization tool. It offers an online evaluation procedure, rating scheme and leadership about green building enterprise, process and organization (Globes, 2009; Kubba, 2012). The genesis of Green Globes, like the LEED and several related schemes all over the world was BREEAM; improve in the UK in the 1980's. There are Green Globes units for New Construction/Important, Renovations Commercial Interiors (i.e. Workplace Fit-ups), Current Buildings (workplaces, multi-residential construction kinds counting workplaces, school, hospitals, hotels, trade, fitness upkeep, academic as well as manufacturing amenities, warehouses, workrooms and sports amenities) (The Data Center Journal, 2013) .

Due to the fact, green building does not considered as a communal rehearsal in Malaysia due to the exclusive problems these programs has (Bin Esa et al., 2011). Though, the Malaysian government stated interest in better application of green constructions (Mokhtar Azizi et al., 2012). In this respect, Malaysia has improved its own resident rating scheme considered as Green Building Index (GBI) to evaluate the environmental enterprise and routine of Malaysian constructions (Aliagha et al., 2013).

The Green Building Index considered as an environmental rating scheme regarding constructions improved through PAM (Pertubuhan Arkitek Malaysia / Malaysian Institute of Architects) and ACEM (the Association of Consulting Engineers Malaysia). The Green Building Index considered as the first inclusive rating scheme for evaluating the ecological enterprise and activity of Malaysian buildings according to the six (6) key standards of energy efficiency, indoor environment quality, sustainable site planning \& management, materials \& resources, water efficiency, and innovation. The Green Building Index is industrialized precisely for the Malaysian humid weather condition, ecological and evolving situation, and cultural as well as social requirements. The Green Building Index initiative attempts to help the construction manufacturing in its march concerning to sustainable improvement (Aliagha et al., 2013; Bahaudina et al., 2013; GREENBUILDINGINDEX, 2009 ).

Green Building Index refers to the first green rating evaluation tools in Malaysia which was designed according to the another international rating scheme like BREEAM and LEED and it was assessed to be modified for the local weather situations (Zainol et al., 2013a).

\subsection{DISCUSSION}

Managing the completed green building needs the responsibility of all groups mainly owners, directors, inhabitants, contractors of building facilities as well as construction operators; in spite, they likewise perceived that using green building management considered as a costly investment (Kamarudin et al., 2013).

Based on the World GBC, the countries are considered into three groups according to their development of the green building standard operation: position of "Established", "Emerging" and "Prospective". Certainly, based on the World GBC majority of regions with "Established" position involved "management" standards in their green building criteria. Table 2 clarifies the indicators regarding per country representing that about the management standards most of the countries with established stage has extra standards of management in their standard. Considering most of the countries in "established" membership status have inclusion of "Management" as one of the criterion in their GB standard, Malaysia is among the few from the countries with "Established" membership that do not has such criteria in the GB standard. 
Table 2 World green building council

\begin{tabular}{|c|c|c|c|c|c|c|c|c|c|c|c|c|c|}
\hline 苞 & 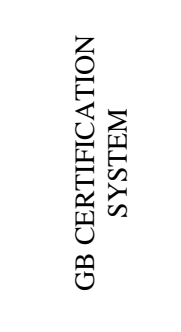 & 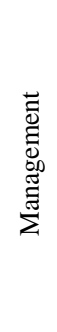 & 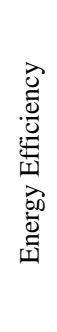 & 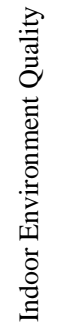 & 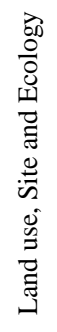 & 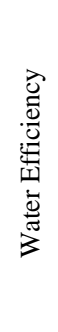 & 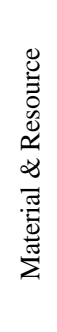 & 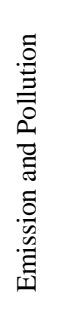 & 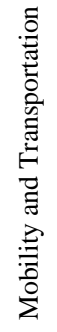 & 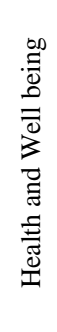 & 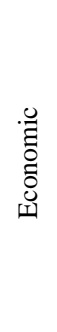 & 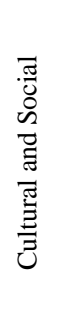 & 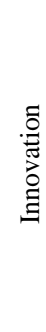 \\
\hline Canada & Green Globe & $\checkmark$ & $\checkmark$ & $\checkmark$ & $\checkmark$ & $\checkmark$ & $\checkmark$ & $\checkmark$ & $\checkmark$ & $\checkmark$ & $x$ & $x$ & $\checkmark$ \\
\hline Colombia & LEED & $x$ & $\checkmark$ & $\checkmark$ & $\checkmark$ & $\checkmark$ & $\checkmark$ & $x$ & $x$ & $x$ & $x$ & $x$ & $\checkmark$ \\
\hline Brazil & LEED & $x$ & $\checkmark$ & $\checkmark$ & $\checkmark$ & $\checkmark$ & $\checkmark$ & $x$ & $x$ & $x$ & $x$ & $x$ & $\checkmark$ \\
\hline US & LEED & $x$ & $\checkmark$ & $\checkmark$ & $\checkmark$ & $\checkmark$ & $\checkmark$ & $x$ & $x$ & $x$ & $x$ & $x$ & $\checkmark$ \\
\hline Dutch & BREEAM-NL & $\checkmark$ & $\checkmark$ & $x$ & $\checkmark$ & $\checkmark$ & $\checkmark$ & $\checkmark$ & $\checkmark$ & $\checkmark$ & $x$ & $x$ & $\checkmark$ \\
\hline France & HQE & $\checkmark$ & $\checkmark$ & $\checkmark$ & $\checkmark$ & $\checkmark$ & $x$ & $\checkmark$ & $x$ & $\checkmark$ & $x$ & $x$ & $x$ \\
\hline German & DGNB & $x$ & $\checkmark$ & $\checkmark$ & $x$ & $\checkmark$ & $\checkmark$ & $\checkmark$ & $\checkmark$ & $\checkmark$ & $\checkmark$ & $\checkmark$ & $x$ \\
\hline Espana & LEED & $x$ & $x$ & $\checkmark$ & $x$ & $x$ & $\checkmark$ & $x$ & $x$ & $x$ & $\checkmark$ & $\checkmark$ & $x$ \\
\hline \multirow{3}{*}{ Polish } & LEED & $\times$ & $\checkmark$ & $\checkmark$ & $\checkmark$ & $\checkmark$ & $\checkmark$ & $x$ & $\times$ & $x$ & $\times$ & $x$ & $\checkmark$ \\
\hline & BREEAM & $\checkmark$ & $\checkmark$ & $x$ & $\checkmark$ & $\checkmark$ & $\checkmark$ & $\checkmark$ & $\checkmark$ & $\checkmark$ & $x$ & $x$ & $\checkmark$ \\
\hline & EU GB & & & & & & & & & & & & \\
\hline Sweden & Eco Effect & $x$ & $x$ & $x$ & $x$ & $x$ & $\checkmark$ & $\checkmark$ & $x$ & $\checkmark$ & $\times$ & $x$ & $x$ \\
\hline \multirow{3}{*}{ Turkish } & LEED & $x$ & $\checkmark$ & $\checkmark$ & $\checkmark$ & $\checkmark$ & $\checkmark$ & $x$ & $x$ & $x$ & $x$ & $x$ & $\checkmark$ \\
\hline & BREEAM & $\checkmark$ & $\checkmark$ & $x$ & $\checkmark$ & $\checkmark$ & $\checkmark$ & $\checkmark$ & $\checkmark$ & $\checkmark$ & $\times$ & $x$ & $\checkmark$ \\
\hline & DGNB & $x$ & $\checkmark$ & $\checkmark$ & $x$ & $\checkmark$ & $\checkmark$ & $\checkmark$ & $\checkmark$ & $\checkmark$ & $\checkmark$ & $\checkmark$ & $x$ \\
\hline UK & BREEAM & $\checkmark$ & $\checkmark$ & $x$ & $\checkmark$ & $\checkmark$ & $\checkmark$ & $\checkmark$ & $\checkmark$ & $\checkmark$ & $x$ & $x$ & $\checkmark$ \\
\hline \multirow{3}{*}{ Emirates } & LEED & $x$ & $\checkmark$ & $\checkmark$ & $\checkmark$ & $\checkmark$ & $\checkmark$ & $x$ & $x$ & $x$ & $x$ & $x$ & $\checkmark$ \\
\hline & BREEAM & $\checkmark$ & $\checkmark$ & $x$ & $\checkmark$ & $\checkmark$ & $\checkmark$ & $\checkmark$ & $\checkmark$ & $\checkmark$ & $x$ & $x$ & $\checkmark$ \\
\hline & Estidama & & & & & & & & & & & & \\
\hline Jordan & LEED & $x$ & $\checkmark$ & $\checkmark$ & $\checkmark$ & $\checkmark$ & $\checkmark$ & $x$ & $x$ & $x$ & $x$ & $x$ & $\checkmark$ \\
\hline Australia & Green Star & $\checkmark$ & $\checkmark$ & $\checkmark$ & $\checkmark$ & $\checkmark$ & $\checkmark$ & $\checkmark$ & $\checkmark$ & $\checkmark$ & $x$ & $x$ & $\checkmark$ \\
\hline \multirow{3}{*}{ Indian } & BREEAM & $\checkmark$ & $\checkmark$ & $x$ & $\checkmark$ & $\checkmark$ & $\checkmark$ & $\checkmark$ & $\checkmark$ & $\checkmark$ & $x$ & $x$ & $\checkmark$ \\
\hline & LEED & $x$ & $\checkmark$ & $\checkmark$ & $\checkmark$ & $\checkmark$ & $\checkmark$ & $x$ & $\checkmark$ & $\checkmark$ & $x$ & $x$ & $\checkmark$ \\
\hline & IGBC & $\checkmark$ & $\checkmark$ & $\checkmark$ & $\checkmark$ & $\checkmark$ & $\checkmark$ & $x$ & $\checkmark$ & $\checkmark$ & $x$ & $x$ & $\checkmark$ \\
\hline Japan & CASBEE & $x$ & $\checkmark$ & $\checkmark$ & $\checkmark$ & $\checkmark$ & $\checkmark$ & $\checkmark$ & $x$ & $\checkmark$ & $x$ & $x$ & $\checkmark$ \\
\hline Singapore & SGBC & $x$ & $\checkmark$ & $x$ & $x$ & $\checkmark$ & $\checkmark$ & $x$ & $x$ & $\checkmark$ & $x$ & $x$ & $\checkmark$ \\
\hline \multirow{2}{*}{ Hong-Kong } & BEAM & $\times$ & $\checkmark$ & $\checkmark$ & $\checkmark$ & $\checkmark$ & $\checkmark$ & $\checkmark$ & $\checkmark$ & $\checkmark$ & $x$ & $x$ & $\checkmark$ \\
\hline & BEAM PLUS & $\checkmark$ & $\checkmark$ & $\checkmark$ & $\checkmark$ & $\checkmark$ & $\checkmark$ & $\checkmark$ & $\checkmark$ & $\checkmark$ & $x$ & $x$ & $\checkmark$ \\
\hline New Zealand & Green Star NZ & $\checkmark$ & $\checkmark$ & $\checkmark$ & $\checkmark$ & $\checkmark$ & $\checkmark$ & $\checkmark$ & $\checkmark$ & $x$ & $x$ & $x$ & $\checkmark$ \\
\hline Malaysia & GBI & $x$ & $\checkmark$ & $\checkmark$ & $\checkmark$ & $\checkmark$ & $\checkmark$ & $x$ & $x$ & $x$ & $x$ & $x$ & $\checkmark$ \\
\hline \multirow{2}{*}{ Finland } & LEED & $x$ & $\checkmark$ & $\checkmark$ & $\checkmark$ & $\checkmark$ & $\checkmark$ & $x$ & $x$ & $x$ & $x$ & $x$ & $\checkmark$ \\
\hline & BREEAM & $\checkmark$ & $\checkmark$ & $x$ & $\checkmark$ & $\checkmark$ & $\checkmark$ & $\checkmark$ & $\checkmark$ & $\checkmark$ & $x$ & $x$ & $\checkmark$ \\
\hline Italia & LEED & $x$ & $\checkmark$ & $\checkmark$ & $\checkmark$ & $\checkmark$ & $\checkmark$ & $x$ & $x$ & $x$ & $x$ & $x$ & $\checkmark$ \\
\hline Panama & LEED & $x$ & $\checkmark$ & $\checkmark$ & $\checkmark$ & $\checkmark$ & $\checkmark$ & $x$ & $x$ & $x$ & $x$ & $x$ & $\checkmark$ \\
\hline Qatar & BREEAM & $\checkmark$ & $\checkmark$ & $x$ & $\checkmark$ & $\checkmark$ & $\checkmark$ & $\checkmark$ & $\checkmark$ & $\checkmark$ & $x$ & $x$ & $\checkmark$ \\
\hline \multirow{2}{*}{ Russia } & LEED & $x$ & $\checkmark$ & $\checkmark$ & $\checkmark$ & $\checkmark$ & $\checkmark$ & $x$ & $x$ & $\times$ & $x$ & $x$ & $\checkmark$ \\
\hline & BREEAM & $\checkmark$ & $\checkmark$ & $x$ & $\checkmark$ & $\checkmark$ & $\checkmark$ & $\checkmark$ & $\checkmark$ & $\checkmark$ & $x$ & $x$ & $\checkmark$ \\
\hline Serbia & LEED & $x$ & $\checkmark$ & $\checkmark$ & $\checkmark$ & $\checkmark$ & $\checkmark$ & $\times$ & $\times$ & $x$ & $x$ & $x$ & $\checkmark$ \\
\hline \multicolumn{2}{|c|}{$\frac{1}{\text { Total }}$} & 14 & 25 & 20 & 22 & 26 & 26 & 18 & 15 & 18 & 3 & 3 & 22 \\
\hline
\end{tabular}

Based on the Table 2 green building certification standard Green Globe, BREEAM, High Environmental Quality (HQE), Green Star, The Building Environmental Assessment Method (BEAM Plus) and Green Star NZ have management practice in green building authorization standard.

The Green Globe standard, there are total of four element covered under the management criteria including IDP, EP, C, and ERP. Integrated design process (IDP) is based on the ECD Energy \& Environment Canada (2004) demonstrates that applying integrated design process makes cost-effective and attains a superior grade of sustainability comparing with the conservative design process. Certainly, this enterprise process can make more important results than did asset in capital equipment. IDP refers to one of the finest equipment which has to help defining the most suitable design track. It delivers the means to use the design policies and move society to sustainability, one scheme at a time (Zimmerman and Eng, 2006). Environmental purchasing (including energy efficient products) is for selecting materials, 
goods and equipment which have slight effect on the setting about the resource usage to drive energy-saving and use high-efficiency tools (ECD Energy \& Environment Canada, 2004). Commissioning is designing, constructing and calibrating the building schemes so they work as desired (ECD Energy \& Environment Canada, 2004). Certainly, green globe exemplifies around 50\% in management performs which will be devoted to the ordering item that contains the organizational scheme, warming, ventilation and air conditioning HVAC scheme, electrical scheme, etc. The aim is that with the commissioned schemes, quality is guaranteed and ecological protection practice is used from the start (Wu and Low, 2010b). Based on the National Institute of Building Sciences (2014) building commissioning is a quickly developing professional rehearsal which is being included by communal and isolated organizations as buildings which are offered based on the owner's purpose, characteristically have less change orders, tend to be more energy efficient, and have inferior process and upkeep charge. Commissioning contributions in the transfer of a project which delivers an effectual, safe and healthy capability; improves; decreases working costs; and develops installed building schemes documentation. Emergency response plan is minimizing the hazard of injury and the environmental effect of emergency occurrences (ECD Energy \& Environment Canada, 2004).

The BREEAM standard, there are total of five element covered under management criteria contain SP, RCP, CSI, SP, SLP\&C. Sustainable procurement is indeed, sustainable procurement considered as an important early stage that with main inducement for reducing their environmental effects and stimulate marketplaces about sustainable yields and facilities (Berry and McCarthy, 2011; Thomson and Jackson, 2007). Additionally, sustainable procurement is sustainable gaining which improves the positive consequences regarding the economy, setting and society (Walker and Brammer, 2009). Sustainable procurement as a procedure in which associations meet their requirements about goods, facilities, works and values in a way which attains value for money on a whole of lifetime foundation for making benefits not merely for the administration, but likewise to society and the economy, through decreasing the damage to the environment (Berry and McCarthy, 2011; Berry et al., 2011). Responsible construction practices is recognizing and encouraging construction sites that are accomplished in an ecologically and generally thoughtful, accountable and liable process (BREGlobal, 2012). This matter should be done in four steps: ecological management, sustainability champion, attentive construction, observing the construction-site influences. Construction site impacts is recognizing and encouraging construction sites accomplished, to purpose ecologically to supply use, energy use and pollution (BREEAM, 2011; BREGlobal, 2012). Stakeholder participation is based on the BREEAM (2011) involved consultation with relates parties, reachable design, structure user data and post-occupancy assessment. Indeed, shareholder input for designing, planning and delivering available practical and comprehensive structures in discussion with existing and upcoming construction users and other investors (BREGlobal, 2012). Service life planning and costing is identifying and encouraging life cycle price and service life development for developing design, requirement and through-life upkeep and process (BREGlobal, 2012).

According to the Green Building Council of Australia (2013), in Green Star standard the management of building performances and amenities considered as an important feature of sustainable activity. The "Management" category evaluates the strategies, actions, goals and policies put in place for ensuring buildings function to their completes sustainable potential. Management standards in Green Star comprise credits addresses the acceptance of sustainable improvement values regarding the project conception over enterprise, manufacture, ordering is enough and significant for all constructions, counting those with simple design and without much equipment, tuning and process. Table 3 illustrates the summary of green building criteria of World GBC.

Table 3 Summaries of green building criteria in World GBC

\begin{tabular}{|cccl|}
\hline Item & Country & $\begin{array}{c}\text { GB Certification } \\
\text { System }\end{array}$ & \multicolumn{1}{c|}{ Management Criteria } \\
\hline 1 & Canada & Green Glob & $\begin{array}{l}\text { Integrated design process, Environmental purchasing (including energy efficient products), } \\
\text { Commissioning, Emergency response plan } \\
\text { Sustainable procurement, Responsible construction practices, Construction site impacts, } \\
\text { Stakeholder participation, Service life planning and cost } \\
\text { Energy management, Water management, Waste management, Repair and maintenance } \\
\text { management } \\
\text { Addresses the adoption of sustainable development principles from project conception } \\
\text { through design, construction, commissioning, tuning and operation }\end{array}$ \\
3 & UK & HQE & $\begin{array}{l}\text { Health, Safety and environmental management } \\
\text { Addresses the adoption of sustainable development principles from project conception } \\
\text { through design, construction, commissioning, tuning and operation }\end{array}$ \\
\hline 5 & France & Green Star & BEAM PLUS \\
\hline
\end{tabular}

For achieving a sustainable development on the usage of GBs required green building management criteria. The management of green buildings considered as a very important factor facing the world since improvement was recognized as one of the key causes of negative influences on setting all over the world (Kamarudin et al., 2013). Preferably, green building standard must have management standards as part of their scheme. As previously mentioned, majority of the countries awarded with "Established", "Emerging" and "Prospective" status by World GBC such as Green Globe in Canada, BREEAM in UK, HQE in France, Green Star in Australia, BEAM Plus in Hong-Kong, Green Star NZ in New Zealand and Green Star SA in South Africa included the management standards in their green building standard.

Furthermore, related green building standards, counting LEED, Comprehensive Assessment System for Building Environmental Efficiency (CASBEE) in Japan, Singapore Green Building Council (SGBC) and Green Building Index (GBI) in Malaysia don't have management standards (Bond and Worzala, 2014; Christensen, 2012a, 2012b; Lowe and Ponce, 2010; Zainol et al., 2013b).

Indeed, Leadership in Energy and Environmental Design (LEED) don't have management practices. In spite, the LEED rating system improves adopting the sustainable green building activities by using the supportive tools and established performance standards. These contain management strategies which attempt to support and/or protect material capitals; prudent energy consumption; and using the natural capitals inside an "environmentally ethical" outline (Ofori-Boadu et al., 2012).

BREEAM is set advanced principles for building management comparing with LEED and Green Star (Reed, 2009). Additionally, the Green Globes allocates $62.7 \%$ of the credits to management criteria, in which LEED and the SGBC merely assign 20 
$30 \%$ of the credits regarding the management standards (Wu and Low, 2010b). Indeed, management criteria considered as critical component to guarantee that the green building will be well managed.

It relates to the point that, the World GBC is functioning inside Asia-Pacific area for improving the advantageous of sustainable building performs, that Malaysia is one of the countries which are looking for to obtain sustainable improvement. On the other hand, there are some potentialities for green building management in Malaysia; but, the findings shows that the lack of management criteria considered as an important critical issue which leads to poor management of green building over Malaysia (Kamarudin, 2013; Zainol et al., 2013a). This paper aims to propose "Management criteria" for Malaysian GBI based on the review of the world green building standards. The proposed "Management Criteria" for Malaysian GBI as follows: 1) Sustainable procurement, 2) Stakeholder participation, 3) Service life planning and costing, 4) Emergency response plan, 5) Energy management, 6) Water management, 7) Waste management, 8) Repair and maintenance management, 9) Adoption of sustainable development principles from project conception through tuning and operation, Health, Safety and Environmental performance. This study proposes nine criteria that abbreviated some of it explained:

\section{Sustainable Procedure}

Sustainable Procurement is that, sustainable procurement involves an organization meeting a need for goods and services in a way that achieves value for money and generates benefits not only to the organization, but also to society and the economy, while minimizing damage to the environment (Australasian Procurement and Construction Council (APCC), 2013; Goverment of Western Australia, 2014; Kalubanga, 2012). Indeed, sustainable procurement practices include strategies that: reduce demand/avoidable consumption/end-of-life disposal; assess future sustainability issues (e.g. energy intensity/costs); support sustainability innovation in tenders; and measure and improve sustainability outcomes (Zeppel, 2014). According to Zeppel (2014) 'sustainable procurement means only purchasing goods that are really needed and buying items or services whose production, use and disposal both minimize negative impacts and encourage positive outcomes for the environment, economy and society. Sustainable procurement looks beyond the traditional procurement focus of value for money, taking into consideration broader factors such as the impact the product, good or service has on the environment; social aspects such as local sourcing and labor conditions; and the performance and track record of the contractor or supplier (Australia), 2012). Sustainable procurement has effect on three aspects such environmental impact (inputs of natural resources energy and water in the manufacture use and disposal of goods), social impact (labor conditions in the manufacture, use and disposal of goods or delivery of services) and economic impact (costs of operation and maintenance over the life of the goods) in the world.

To recognize and encourage life cycle costing and service life is planning in order to improve design, specification and throughlife maintenance and operation. Building service life planning is an important aspect of green building. Indeed, service life planning is not a new concept although the term may be unfamiliar.

\section{Service Life Planing and Costing}

Service life planning can improve the economic and environmental impacts of the building. It manages the most costly portion of a building's life cycle costs, the operation and maintenance stage. And, by guiding appropriate and necessary investments over the course of the building's life cycle, increases the residual value of the building. Additionally, service life planning manages environmental impacts. Extending the service life of the building and reducing maintenance and replacements contributes to achieving sustainable development and preservation of scarce resources (Guide and Specifiers, 2010). Stakeholder participation has emerged as suitable approach for boosting natural resources management. As respect, contrary long examination with participation, there are still probability for recovery in designing a procedure of stakeholder contention by addressing stakeholder dissimilarity and the complication of decision-making procedure (Luyet et al., 2012).

\section{Emergency Response Plan}

Emergency response plan that for incidents derived from natural causes or for those that derive from human actions demand both persistent and consistent liaison and coordination among a large diversity of governmental agencies, response organizations, and community support resources ("Preface," 1999). The purpose of this emergency response plan is to establish an organizational structure and procedures for response to major emergencies. It assigns the roles and responsibilities for the implementation of the plan during an emergency following the incident command system model. Emergency response plan contains predetermined guidelines and procedures to ensure the safety, health, and welfare of staff, and an immediate response to an emergency or disaster situation. An emergency is any disruptive or harmful event that endangers people, environment, or an organization's property and assets. Emergencies can be small, as in afire contained by employees using firefighting equipment, or large, as in a disaster resulting from an earthquake or a tornado (sentryx 1, 2009).

\section{Energy Management}

According to White paper (2014) energy management means using technology in an intelligent way to better manage energy use across a site. Energy management plays a direct role in finding and eliminating sources of energy waste. In fact, energy management causes to savings on energy bills, decreasing $\mathrm{CO} 2$ emissions and even reducing maintenance costs. Also, energy management can also form part of a comprehensive strategy to improve the environmental profile of an organization. Energy management planning involves more than reducing energy consumption and improving energy efficiency. Implementation of energy management practices can also have ancillary effects, such as an improvement in staff communications, morale, and understanding of the treatment process (Pirnie, 2010). Realistically, the facilities management believes that manages energy plays an important role in achieving energy efficiency performance (Mokhtar Azizi et al., 2012). In other words, approaching to energy efficiency in industry through the adoption of energy management practices (Kannan and Boie, 2003; Thollander and Ottosson, 2010). Energy management is a means to overcome barriers to energy efficiency (Thollander and Ottosson, 2010). As well as, energy management becomes a dynamic process where new ideas and knowledge are 
generated, which, in turn, produces additional energy efficiency gains (Kannan and Boie, 2003). Energy management is an effective tool to use to reduce costs and improve competitiveness while demonstrating leadership and environmental stewardship (Nesler, 2013). Some important elements in energy management include an initial energy audit, senior management's support, monitoring of energy use, an energy policy, a program for energy saving projects, and staff motivation and training (Thollander and Ottosson, 2010).

\section{Water Management}

A successful water management program starts with developing a comprehensive water management plan. This plan should be included within existing facility operating plans. Water management plans should provide clear information about how a facility uses water from the time it is piped in to its ultimate disposal. Knowing how water is used and what it costs enables Federal agencies to make appropriate water management decisions.

\section{Waste Management}

Poor management of waste led to contamination of water, soil and atmosphere and to a major impact on public health. Some of the direct health impacts of the mismanagement of waste are well known and can be observed especially in developing countries (Giusti, 2009).

\section{Repair and Maintennance}

Maintenance and repair is a complex process. The maintenance and repair committee is responsible for planning and supervising all maintenance and repair activity in the building. Maintenance and repair play a crucial role in the life of building, and successful maintenance and repair depends on solid performance of other aspects of building management: budgeting, committees, participation, rent collection and communication (York). The maintenance and repair committee is responsible for planning and supervising all maintenance and repair activity in the building. The committee must work closely with the tenant association officers in order to figure out how much money is available for repairs, and how it should be used (York). Repair and Maintenance activities, when planned effectively, can affect performance to reducing the risk (Grussing and Liu, 2013). Repair and Maintenance can be broken down into three different categories: Routine Maintenance, Preventive Maintenance, and Deferred Maintenance. Maintenance is now being largely accepted and recognized as the best approach in ensuring the prolongation of the buildings' lifespan, a strategy for slow renewal and decay prevention; and, maintaining utility and economic return (Rashid and Ahmad, 2011). Finally, maintenance and repair play a crucial role in the life of the building, and successful maintenance and repair depends on solid performance of other aspects of building management: budgeting, committees, participation, rent collection and communication (York).

According World GBC Australia management category (2015) adoption of sustainable development principles from project conception by tuning and operation, following practical accomplishment and pervious to occupation, the landlord clientele must commit to a tuning process of all nominated systems. At least, the commitment must contain quarterly arrangement and measurement for the first 12 months after occupation and a 10th month review of disclaimer. Finally, health, safety and environmental performance are significant item for residents during life.

\subsection{CONCLUSION}

In summary, the paper has highlighted the significance of the inclusion of "Management" criteria in Malaysian GB Standard. Moreover, the findings signifies that the presence of management criteria in Malaysian GBI inspire the necessity of the including that in the GBI implementation in Malaysia, that has important role in developing the sustainability agenda on account of its possible contribution to the country sustainability aims in GB. Total of nine practice has been proposed for the Management criteria for Malaysian GBI: Sustainable procurement, Stakeholder participation, Service life planning and costing, Emergency response plan, Energy management, Water management, Waste management, Repair and maintenance management, Adoption of sustainable development principles from project conception through tuning and operation, Health, Safety and Environmental performance.

\section{References}

Abdullah, S., Abdul Razak, A., Hanafi, M. H., and Salleh, M. N. (2011). Managing Government Property Assets: The Main Issues From The Malaysian Perspective. Journal of Techno-Social, 3(1).

Aliagha, G. U., Hashim, M., Sanni, A. O., and Ali, K. N. (2013). Review of Green Building Demand Factors for Malaysia. Journal of Energy Technologies and Policy, 3(11), 471-478.

Australasian Procurement and Construction Council (APCC). (2013). Sustainable Procurement Practice Note. Australian and New Zealand Government Framework for Sustainable Procurement.

Australia, G. B. C. (2009). Green Star. Green Building Council of Australia (2013). Green Building Council of Australia.

Australia, F. M. A. o. A. L. F. (2012). Facilities Management Good Practice Guide. Facility Management Association of Australia Ltd (FMA Australia)

Bahaudina, A. Y., , E. M. E., and , A. M. S. (2013). A Comparison of the Green Building's Criteria.

Banani, R., Vahdati, S. D. M., and Elmualim, A. (2011). A Sustainable Assessment Method For Non-Residential Buildings in Saudi Arabia: Development Of Criteria. School of Construction Management and Engineering, University of Reading, Reading.

Begum, R. A., and Pereira, J. J. (2010). GHG Emissions And Energy Efficiency Potential In The Building Sector of Malaysia. Australian Journal of Basic and Applied Sciences, 4(10), 5012-5017.

Berry, C., and McCarthy, S. (2011). Guide to sustainable procurement in construction, London: CIRIA

Berry, C., McCarthy, S., Sustainability, A., and Enterprise, S. (2011). Guide to Sustainable Procurement In Construction: CIRIA London.

Bin Esa, M. R., Marhani, M. A., Yaman, R., Noor, A. A. H. N. H., and Rashid, H. A. (2011). Obstacles in Implementing Green Building Projects in Malaysia. Australian Journal of Basic and Applied Sciences, 5(12), 1806-1812. 
Bond, S. (2011). Barriers and drivers to green buildings in Australia and New Zealand. Journal of Property Investment \& Finance, 29(4), 494-509.

Bond, S., And Worzala, E. (2014). Green Buildings. Private Real Estate Markets and Investments, 234.

BREEAM. (2011). Construction site impacts. BREGlobal Ltd

BREGlobal. (2012). BREEAM New Construction. BREGlobal Ltd

Cassidy, R. (2003). White Paper On Sustainability. Building Design and Construction, 10.

Christensen, P. (2012a). Assessing Assessment: Toward a More Holistic Rating System for Sustainability Performance. European Real Estate Society (ERES)

Christensen, P. (2012b). Key Strategies of Sustainable Real Estate Decision-Making in the United States: A Delphi Study of the Stakeholders.

Crawley, D., and Ilari, A. (1999). Building Environmental Assessment Methods: Applications And Development Trends. Building Research \& Information, 27(4-5), 300-308.

Ding, G. K. C. (2008). Sustainable Construction-The Role Of Environmental Assessment Tools. Journal of Environmental Management, 86(3), 451-464.

ECD Energy \& Environment Canada. (2004). Green Globes TM Design for New Buildings Design for New Buildings and Retrofiand Retrofi and Retrofits and Retrofitsts.

Geng, Y., Dong, H., Xue, B., and Fu, J. (2012). An Overview of Chinese Green Building Standards. Sustainable Development, 20(3), 211-221.

Giusti, L. (2009). A review of waste management practices and their impact on human health. Waste Management, 29( 8), 2227-2239

Globes, G. (2009). Green Globes. Transportation, 7(10.1), 4.1.

Goodman, F. (2008). Integrating Green Practice into your Building Management Strategy.

Goverment of Western Australia. (2014). Sustainable Procurement Practice Guidelines.

Greenbuildingindex. ( 2009 ). Gbi Assessment Criteria For

Non-Residential New Construction (Nrnc).

Guide, W. B. D., And Specifiers, F. G. C. G. F. (2010). Facility Service Life Requirements.

Halim, M. (2012). Economic Issues On Green Office Buildings in Malaysia.

Hong, W., Chiang, M. S., Shapiro, R. A., and Clifford, M. L. (2007). Building Energy Efficiency

Why Green Buildings Are Key to Asia's Future.

Hwang, B.-G., and Tan, J. S. (2012). Green Building Project Management: Obstacles And Solutions For Sustainable Development. Sustainable Development, 20(5), 335-349.

Initiative, C. (2009). Buildings and Climate Change.

Kalubanga, M. (2012). Sustainable Procurement: Concept, and Practical Implications for the Procurement Process, 1, 01-07.

Kamarudin, N. (2013). Green Property Management Practice in Malaysia.

Kamarudin, N., Razak, S. M. A., Sapri, M., Mahamud, R., Daud, D., and Sipan, I. (2013). Green Property Management Practice in Malaysia.

Kannan, R., and Boie, W. (2003). Energy Management Practices In SME-Case Study Of A Bakery in Germany. Energy Conversion and Management, 44(6), 945959.

Kasai, N., and Jabbour, C. J. C. (2014). Barriers to Green Buildings At Two Brazilian Engineering Schools. International Journal of Sustainable Built Environment, $3(1), 87-95$

Kubba, S. (2012). Handbook Of Green Building Design And Construction: Leed, Breeam, and Green Globes: Butterworth-Heinemann.

Lowe, C., and Ponce, A. (2010). UNEP-FI/SBCI's Financial \& Sustainability Metrics Report: UNEP-Financial Intiative (FI)/Sustainable Buildings and Construction Initiative (SBCI). Retrieved November.

Luyet, V., Schlaepfer, R., Parlange, M. B., and Buttler, A. (2012). A Framework To Implement Stakeholder Participation In Environmental Projects. Journal of Environmental Management, 111, 213-219.

Mokhtar Azizi, N. S., Fassman, E., Wilkinson, S., and Che Ani, A. I. (2012). Management Practice to Achieve Energy Efficiency Performance: Green versus Conventional Office Building in Malaysia. Journal of Legal Affairs and Dispute Resolution in Engineering and Construction, 5(4), 205-214.

Nesler, C. (2013). Global Energy Management Practices, Standards Increase Plant Profitability.

Ofori-Boadu, A., Owusu-Manu, D.-G., Edwards, D., and Holt, G. (2012). Exploration Of Management Practices For LEED Projects: Lessons From Successful Green Building Contractors. Structural Survey, 30(2), 145-162.

Pirnie, M. (2010). Water \& Wastewater Energy Management. New York State Energy Research \& Development Authority

Preface. (1999). In P. A. Erickson (Ed.), Emergency Response Planning (pp. xiii-xiv). San Diego: Academic Press.

Reed, R. B., Anita Wilkinson, Sara Schulte, Karl-Werner. (2009). International Comparison of Sustainable Rating Tools. The Journal of Sustainable Real Estate, 1(1), $1-22$

Richardson, G. R. A., and Lynes, J. K. (2007). Institutional Motivations And Barriers To The Construction Of Green Buildings On Campus: A Case Study of the University of Waterloo, Ontario. International Journal of Sustainability in Higher Education, 8(3), 339-354.

sentryx1. (2009). Emergency Response Plan Template.

Seo, S. (2002). International Review Of Environmental Assessment Tools And Databases.

Shaikh, P. H., Nor, N. B. M., Nallagownden, P., Elamvazuthi, I., and Ibrahim, T. (2014). A Review On Optimized Control Systems For Building Energy And Comfort Management Of Smart Sustainable Buildings. Renewable and Sustainable Energy Reviews, 34(0), 409-429.

The Data Center Journal. (2013). Green Globes $₫$ - A Practical, Web-based Alternative to Leed.

The World Green Building Council. (2009). Six Continents, One Mission

V. Rauland, P. Newman (2015). How green building is shaping the global shift to a low carbon economy. [Report]. Springer International Publishing Switzerland.

Thollander, P., and Ottosson, M. (2010). Energy Management Practices In Swedish Energy-Intensive Industries. Journal of Cleaner Production, 18(12), 1125-1133.

Thomas, S. (2008). A Discussion Document Comparing International Environmental Assessment Methods For Buildings.

Thomas Saunders. (2008). A Discussion Document Comparing International Environmental Assessment Methods For Buildings.

Thomson, J., and Jackson, T. (2007). Sustainable procurement in practice: Lessons from local government. Journal of Environmental Planning and Management, 50(3), 421-444.

Tiun, L. T. (2006). Managing high-rise residential building in malaysia: where are we. Persatuan Sains Sosial, Universiti Putra Malaysia, 8-10.

Walker, H., and Brammer, S. (2009). Sustainable procurement in the United Kingdom public sector. Supply Chain Management: An International Journal, 14(2), 128137.

Wu, P., and Low, S. (2010a). Project Management and Green Buildings: Lessons from the Rating Systems. Journal of Professional Issues in Engineering Education and Practice, 136(2), 64-70.

Wu, P., and Low, S. P. (2010b). Project Management And Green Buildings: Lessons From The Rating Systems. Journal of Professional Issues in Engineering Education and Practice, 136(2), 64-70.

Zainol, N. N., Woon, N. B., Ramli, N. A., and Mohammad, I. S. (2013a). Barriers of Implementing Green Building Maintenance: A Preliminary Survey.

Zainol, N. N., Woon, N. B., Ramli, N. A., and Mohammad, I. S. (2013b). Barriers Of Implementing Green Building Maintenance: A Preliminary Survey.

Zeppel, H. (2014). Green Procurement By Local Government: A Review Of Sustainability Criteria: University of Southern Queensland.

Zhang, X., Platten, A., and Shen, L. (2011). Green Property Development Practice In China: Costs And Barriers. Building and Environment, 46(11), 2153-2160.

Zimmerman, A., and Eng, P. (2006). Integrated design process guide. Canada Mortgage and Housing Corporation, Ottawa. 